\title{
Chemosensitivity testing by nuclear damage assay of needle biopsy tissue in 19 patients with advanced pancreatic cancer
}

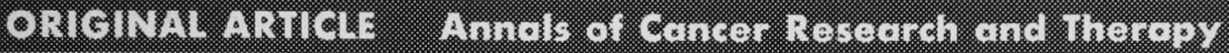

\author{
Hiromitsu Saisho. Taketo Yamaguchi . Tadamichi Denda*1, \\ Hisashi Tokita. Masao Ohto*2i
}

\begin{abstract}
At present, chemoterapy still achieves poor results in advanced pancreatic cancer and sometimes the patient's quality is impaired by useless chemotherapy. To improve this situation, we used the nuclear damage assay (NDA) as a chemosensitivity test for pancreatic cancer. We performed the NDA on percutaneous needle biopsy tissue obtained from 19 patients with inoperable advanced pancreatic cancer, and 16 of them were successfully assayed by the chemosensitivity test. We could get a positive response to the assay in 13 of the 16 patients. The 13 patients with a positive response were treated with the agent selected by the NDA, while 3 patients with no response were treated with 5FU. The outcome of chemotherapy was a complete response in one patient, no change in 5 , and progressive disease in 7 of the patients showing tumor sensitivity in the assay. On the other hand, only progressive disease was found in the patients with no response in the assay. The survival rate of the former group was better than the latter $(P<0.05)$, and the median survival time was 23.4 and 11 . 1 weeks, respectively. We also report in detail the patient with a complete response to VP 16 , which is rarely effective against pancreatic cancer. These results suggest that NDA of percutaneous needle biopsy tissue might improve the efficacy of chemotherapy for advanced pancreatic cancer.

Ann Cancer Res Ther $3(2): 103 \sim 108,1994 /$ Received 22 July 1994 , Accepted 11 Oct. 1994

Key words : advanced pancreatic cancer, chemotherapy, nuclear damage assay, needle biopsy
\end{abstract}

Pancreatic cancer is generally detected at an advanced stage so that about two third of the patients are unsuitable for surgical resection ${ }^{11}$.

Although chemotherapy has an important role in the treatment of advanced pancreatic cancer, it is not yet very reliable. At present, there are not many effective anticancer agents and tumor sensitivity varies with the type of cancer and even changes during treatment. If it was possible to reliably select an effective anticancer agent on the basis of chemosensitivity testing, the results of chemotherapy would be greatly improved.

Accordingly, we investigated chemosensitivity testing by the nuclear damage assay (NDA) in patients with advanced pancreatic cancer. The tumor tissue for assay was obtained by percutaneous needle biopsy. Our results indicated that chemosensitivity testing of needle biopsy tissue was useful for determining the appropriate chemotherapy for advanced pancreatic cancer.

\footnotetext{
"1)The First Department of Medicine, Chiba University School of Medicine,

-2) Chiba Cancer Research Institute

Correspondence to : Hiromitsu Saisho,

The First Department of Medicine, Chiba University School of Medi-

cine, 1-8-1, Inohana, Chuo-Ku, Chiba 260, Japan

TEL. 043-222-7171, FAX. 043-225-3492
}

\section{Materials and methods}

\section{Patients}

From June 1991 to March 1994, this study was carried out in 19 patients with advanced pancreatic cancer treated at Chiba University Hospital. The patients were 11 men and 8 women aged from 49 to 78 years (mean : 63.8 years). Chemotherapy based on the test results was performed in 16 patients. A definitive histological diagnosis was made by percutaneous biopsy in all patients. Inoperability was determined from the finding of invasion into neighboring organs including major vessels and/or distant metastasis on imaging diagnosis (US, CT and angiography).

\section{Tumor biopsy}

We collected tumor tissue samples by percutaneous needle biopsy under ultrasonic guidance ${ }^{2)}$ using a 21 gauge biopsy needle that was $6.8 \mathrm{~mm}$ in diameter and $170 \mathrm{~mm}$ long (Sonopsy Cl, Hakko Co., Ltd.). The amount of tissue collected was approximately $0.8 \mathrm{mg}$ in dry weight, or about 10,000 cells on average $(5,000$ 20,000 ) as counted by flowcytometry.

Biopsy was usally performed three times in one session. One of the specimens was used for histological examination and the other two were used for the chemosensitivity assay. The tissue was immediately suspended in RPMI 1640 medium (adjusted to $\mathrm{pH} 7.2$ 


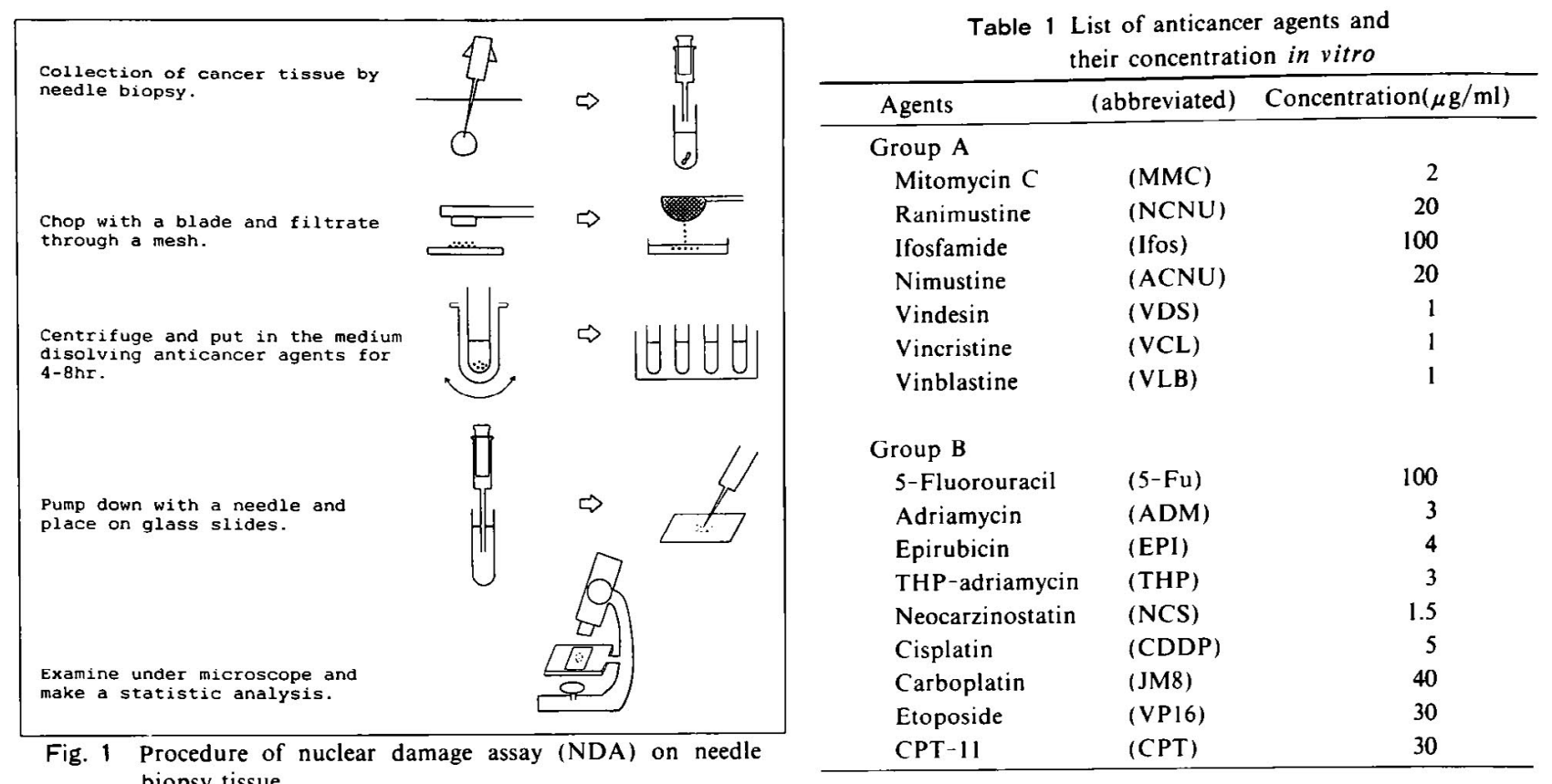

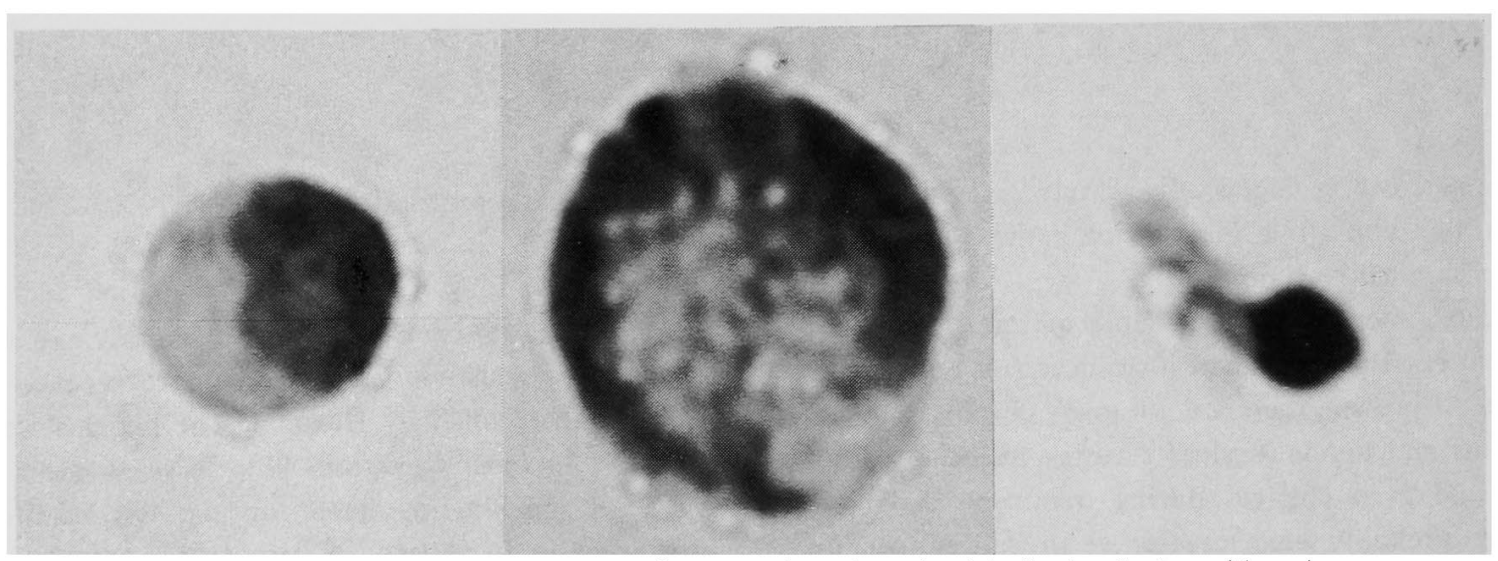

Fig. 2 Tumor nuclei shows no change(a). destruction (b) and condensation (c) after incubation with anticancer agent

with $\mathrm{NaOH}$ ) supplemented with $10 \%$ fetal bovine serum and was stored at $0 \sim 4^{\circ} \mathrm{C}$ until assay within 24 hours after biopsy.

Informed consent was obtained from all the patients before biopsy.

\section{Nuclear damage assay}

The assay was carried out according to method of Tokita ${ }^{3,4}$. The tumor tissues were minced into pieces with a blade, and then suspended in the medium and filtered through a mesh to remove mesenchymal components and to obtain micro cell aggregates. The filtered material was then centrifuged at $1,000 \mathrm{rpm}$ for 5 minutes to eliminate fatty and necrotic tissue components in the supernatant. The micro cell aggregates were next suspended in medium containing anticancer agents at the speci- fied concentrations and incubated for $4 \sim 8$ hours. Other cell aggregates were incubated in medium with no anticancer agents as a control. Then the aggregates were repeatedly pumped through a needle injector to disperse them, and cells deposited at the bottom were placed on glass slides (Fig.1). More than 100 cells per slide were observed. When destruction, disintegration, or condensation of the tumor cell nuclei were noted, the cells were regarded as sensitive to the chemotherapy agent being tested (Fig.2). The number of cells which showed chemosensitivity was compared with the control by the $\mathrm{X}^{2}$ test or Fisher's test, and $\mathrm{P}<0.05$ was taken to indicate a significant difference. The anticancer agents were divided into group A and B according to the nuclear changes produced. Group A agents caused nuclear disintegration or destruction and group $\mathbf{B}$ agents caused 
Table 2 Chemosensitivity test results, actual chemotherapy, and prognosis

\begin{tabular}{|c|c|c|c|c|c|}
\hline $\begin{array}{l}\text { Patient } \\
\text { No. }\end{array}$ & $\begin{array}{l}\text { Anticancer } \\
\text { agents tested }\end{array}$ & $\begin{array}{l}\text { Active } \\
\text { agents }\end{array}$ & $\begin{array}{l}\text { Agent } \\
\text { used }\end{array}$ & Response & $\begin{array}{l}\text { Survival } \\
\text { (weeks) }\end{array}$ \\
\hline 1 & $\begin{array}{l}\text { CDDP, MCNU, } 5 F U, \text { Epi } \\
\text { VPI6, MMC, CPT }\end{array}$ & VP16 & VP16 & $\mathrm{CR}$ & 92.7 \\
\hline 2 & $\begin{array}{l}\text { JM8, NCS, 5FU, VPI6 } \\
\text { MMC, Ifos, ACNU, VDS }\end{array}$ & VDS & VDS & NC & 39.8 \\
\hline 3 & $\begin{array}{l}\text { CDDP, JM8, MCNU, THP, ADM } \\
\text { NCS, } 5 \text { FC, Epi, VP16, MMC } \\
\text { CPT }\end{array}$ & $\begin{array}{l}\text { CDDP, NCS } \\
\text { CPT }\end{array}$ & CDDP & $\mathrm{NC}$ & 18.9 \\
\hline 4 & $\begin{array}{l}\text { JM8, } 5 F U, \text { Ifos, ACR } \\
\text { MMC, MCNU }\end{array}$ & JM8 & JM8 & $\mathrm{NC}$ & 18.6 \\
\hline 5 & $\begin{array}{l}\text { VDS, JM8, NCS, 5FU, VP16 } \\
\text { MMC, Ifos, THP, ACNU }\end{array}$ & THP & THP & $\mathrm{NC}$ & 17.2 \\
\hline 6 & $\begin{array}{l}\text { CDDP, } 5 F U, \text { Epi, VP } 16 \\
\text { MMC, CPT }\end{array}$ & CDDP & CDDP & $\mathrm{NC}$ & 12.3 \\
\hline 7 & $\begin{array}{l}\text { CDDP, ADM. 5FU, Epi } \\
\text { VP16, MMC }\end{array}$ & MMC & MMC & PD & 22.3 \\
\hline 8 & ADM. 5FU, MMC & MMC & MMC & $\mathrm{PD}$ & 21.4 \\
\hline 9 & $\begin{array}{l}\text { CDDP, VDS, JM8, MCNU, THP } \\
\text { NCS, 5FU, VP16, MMC, CPT }\end{array}$ & CDDP & CDDP & PD & 17.6 \\
\hline 10 & $\begin{array}{l}\text { VDS, JM8, THP, } 5 F U \\
\text { Ifos, MMC }\end{array}$ & $5 \mathrm{FU}$ & $5 \mathrm{FU}$ & PD & 16.3 \\
\hline 11 & $\begin{array}{l}\text { CDDP, JM8, MCNU, NCS } \\
\text { 5FU, MMC, Ifos, CPT }\end{array}$ & JM8 & JM8 & PD & 14.7 \\
\hline 12 & $\begin{array}{l}\text { JM8, ADM, NCS, 5FU } \\
\text { Epi, MMC, CPT, ACR }\end{array}$ & ADM, NCS & ADM & PD & 14.1 \\
\hline 13 & $\begin{array}{l}\text { CDDP, MCNU, THP, ADM, NCS } \\
\text { 5FU, Epi, VP16, MMC, CPT }\end{array}$ & Epi & Epi & PD & 13.4 \\
\hline 14 & $\begin{array}{l}\text { CDDP, 5FU, EPI. VP16 } \\
\text { MMC, CPT }\end{array}$ & (None) & $5 \mathrm{FU}$ & PD & 19.0 \\
\hline 15 & CDDP, 5FU, Epi, MMC & (None) & $5 \mathrm{FU}$ & PD & 14.9 \\
\hline 16 & $\begin{array}{l}\text { JM8, 5FU, Epi, VP } 16 \\
\text { MMC, ACNU }\end{array}$ & (None) & $5 \mathrm{FU}$ & PD & 10.7 \\
\hline
\end{tabular}

condensation. Table 1 shows the anticancer agents and the concentration of each agent used in the assays. Group A consisted mainly of alkylating agents and vinka alkaloids, while group B consisted of antibiotics and antimetabolites. The in vitro concentrations were adjusted to correspond to the maximum blood level of each agent in clinical use.

\section{Chemotherapy}

Active anticancer agents were selected from the results of the assay and patients were treated with these agents. When there were more than 2 or more active agents, we chose the one causing the highest level of nuclear damage and gave it intravenously at the standard dosage. Patients whose tumors showed no response to any anticancer agents were treated with $S F U$ at a dose of $500 \mathrm{mg} / \mathrm{m}^{2}$ for 5 days.

The response to chemotherapy was evaluated every 4 weeks according to the general rules for chemotherapy of solid tumors developed by the Japan Society of Cancer
Therapy ${ }^{5}$. Survival time was determined according to the Kaplan-Meier method and differences in survival were assessed by the generalized Wilcoxon test.

\section{Results}

\section{Chemosensitivity assay}

The assay was technically successful in 16 of $19 \mathrm{pa}^{-}$ tients $(84.2 \%)$. Because of an insufficient amount of tissue, we could not judge tumor sensitivity in other 3 patients. On an average, 6.7 anticancer agents were successfully tested in one assay. We obtained a positive response in 13 of 16 patients and there were 1.2 active agents on average (Table 2). The active rate for each agent is shown in Table 3. CDDP and JM8 showed relatively higher rates than the other agents.

\section{Chemotherapy}

In the patients treated with anticancer agents selected as active by the assay, the following results were obtained: 
Table 3 The activity of each anticancer agent in the chemosensitivity assay

\begin{tabular}{cll}
\hline Agent & \multicolumn{2}{l}{ Active $/$ Total(\%) } \\
\hline CDDP & $1 / 8$ & $(37.5)$ \\
VDS & $1 / 3$ & $(33)$ \\
JM8 & $2 / 9$ & $(22)$ \\
MCNU & $1 / 5$ & $(20)$ \\
THP & $1 / 6$ & $(16.7)$ \\
ADM & $1 / 6$ & $(16.7)$ \\
NCS & $1 / 7$ & $(14.3)$ \\
5-FU & $2 / 16$ & $(12.5)$ \\
Epi & $1 / 9$ & $(11)$ \\
VP16 & $1 / 10$ & $(10)$ \\
MMC & $1 / 16$ & $(6.3)$ \\
Ifos & $0 / 5$ & \\
ACNU & $0 / 3$ & \\
CPT & $0 / 7$ & \\
ACR & $0 / 3$ & \\
\hline
\end{tabular}

complete response (CR) in one, no change (NC) in 5 and progressive disease (PD) in 7. On the other hand, all of the patients with no active agents detected by the test showed PD. The survival rate of the group with sensitive tumors was significantly better than that of the group without sensitive tumors $(P<0.05)$ (Fig.3). The median survival time was 23.4 and 11.1 weeks, respectively.

\section{A Casa report : advanced pancreatic cancer with a complete response (CR)}

The patient was a 75-year-old man who presented to hospital because of upper abdominal pain. Ultrasonography detected a low-echogenicity tumor $(30 \mathrm{~mm}$ in diameter) in the body of the pancreas and also multiple small tumors in the liver. Needle biopsy proved that the tumor was a moderately differentiated adenocarcinoma. The patient was also found to be unsuitable for surgical resection. Chemosensitivity testing showed that VP-16 was active against the tumor, and we treated him with this agent at a dose of $80 \mathrm{mg} / \mathrm{m}^{2}$ for 2 courses. After this intravenous chemotherapy, the patient also took the agent orally at a daily dose of $25 \mathrm{mg}$.

After 4 months of treatment, both the primary and metastatic lesions had disappeared on abdominal CT scans and CR was confirmed (Fig. 4). The serum levels of CA19-9 and SPAN-1 decreased markedly from 1,820 to 44 and from 390 to 35 , respectively (Fig.5). After treatment, he survived for one year and 10 months, but finally died of malnutrition that was probably due to tumor regrowth.

\section{Discussion}

Various kinds of anticancer agents have been used for the treatment of inoperable advanced pancreatic cancer, although the response rate (CR plus PR) still remains

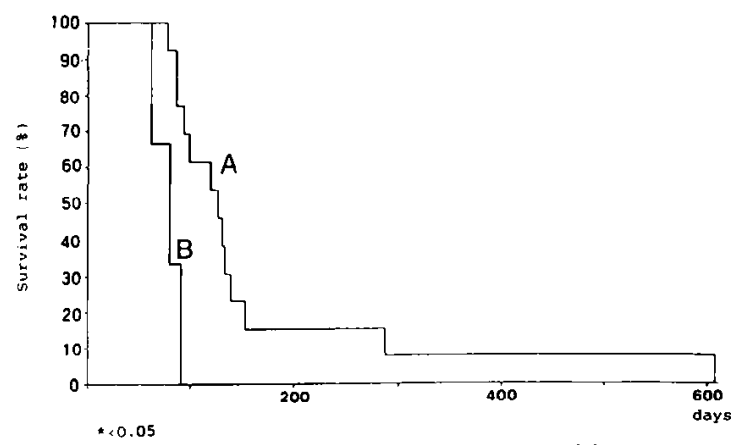

Fig. 3 Survival of patients with the positive group (A) and the negative group (B) in the sensitivity according to chemotherapy.

under $20 \%$ at present ${ }^{6,7}$. Thus, more effective anticancer agents need to be developed. Adverse effects due to the administration of anticancer agents are a serious probrem, since the quality of life of cancer patients can be greatly reduced by the use of chemotherapy with no therapeutic effect. In this situation, chemosensitivity testing is clinically important to prevent the inappropriate use of such agents.

Although various chemosensitivity tests have been reported previously ${ }^{8-11)}$, only a few of them can be used clinically. A chemosensitivity test applicable to clinical use should have the following features : (1) simple and reliable technique, (2) a high success rate, (3) rapid results, and (4) a good correlation with therapeutic responses such as tumor regression and long survival. Current tests also require a large amount of cancer tissue to be surgically resected and so have been used mainly for adjuvant therapy accompanied by operative intervention ${ }^{12)}$. Accordingly, we generally have to undertake chemotherapy without sensitivity testing in patients with inoperable pancreatic cancer.

The nuclear damage assay (NDA) used in the present study reguires only a small amount of cancer tissue, and is a simple and reliable technique. Assessment can be completed in a relatively short period of less than 48 hours. Moreover, it has been shown that the NDA is more closely correlated with the nude mouse method than either the MTT assay or colony formation inhibition assay ${ }^{13)}$.

In this study, we performed the NDA on a small amount of cancer tissue obtained by percutaneous needle biopsy and proved that it could be successfully used in daily clinical practice. According to the results of the NDA, we selected an appropriate anticancer agent for chemotherapy. As a result, the cancers sensitive to a certain agents tended to show a better response to therapy. It was noteworthy that CR was achieved in a case of advanced pancreatic cancer by using VP-16, which is rarely effective for this type of cancer ${ }^{14}$. Although $5 \mathrm{FU}$ is generally used as the first-line anticancer agent, the 

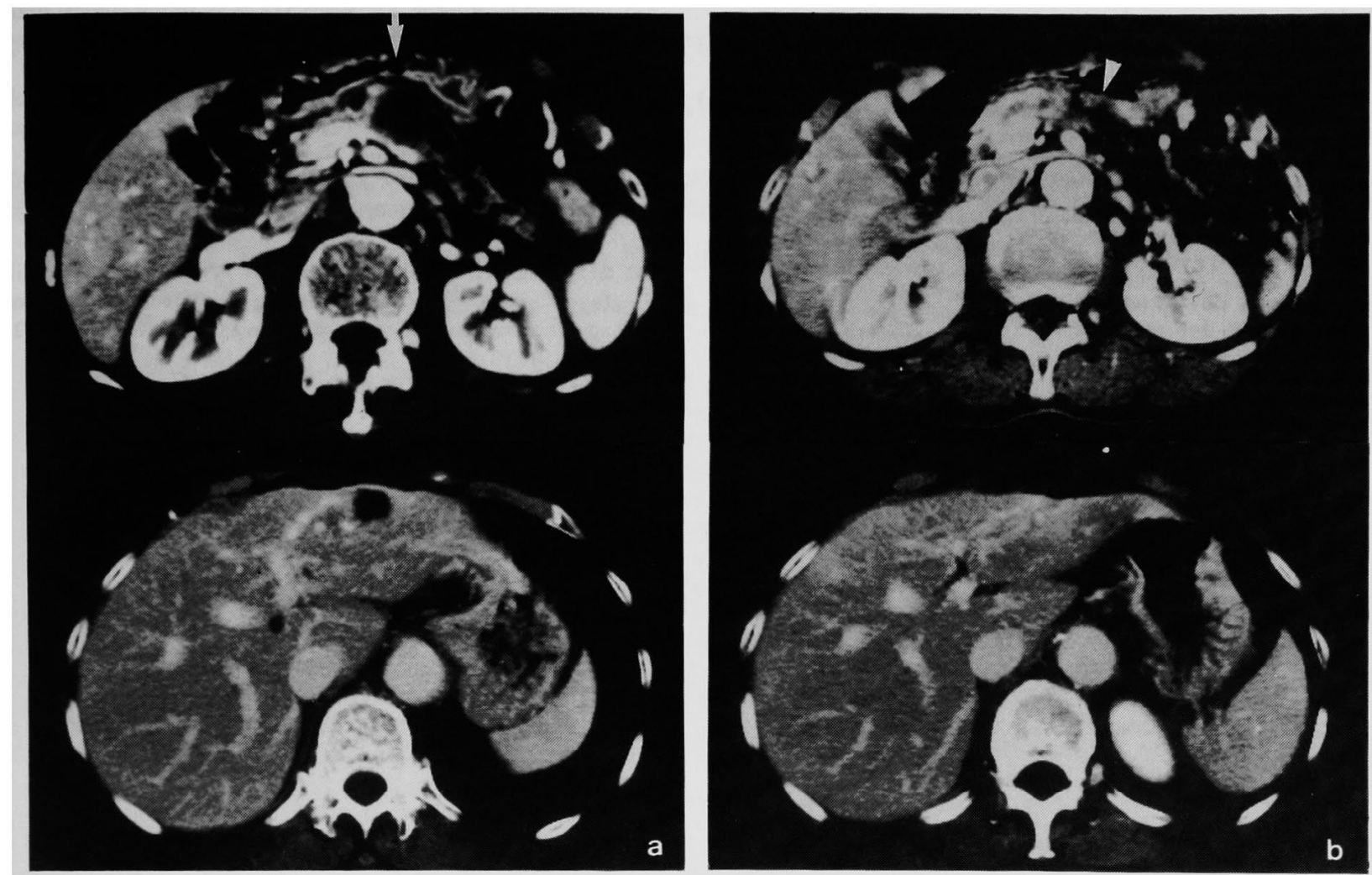

Fig. 4 The case of complete response

a : Dynamic X-ray CT scan before treatment demonstrates that the low density tumor in the body of the pancreas (arrow) accompanied by dilated main pancreatic duct and the metastatic liver tumors.

b : 4 months after the treatment, both the pancreas and the liver tumors disappeared. Only dilated main pancreatic duct is noted (arrow head).

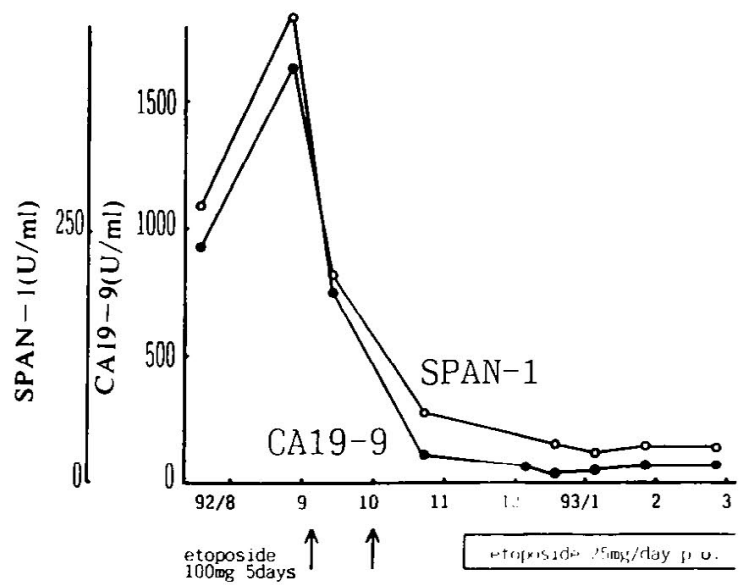

Fig. 5 Change of the tumor markers before and after the treatment

sensitivity rate was only $12.5 \%$ in the NDA assay. This means that we can expect better results when an appropriate anticancer agent is given based on the NDA assay than when $5 F U$ is selected at random. In addition, NDA of percutaneous needle biopsy tissue might possibly improve the efficacy of chemotherapy in the treatment of advanced pancreatic cancer, which usually requires laparotomy for the collection of tissue.

However, there is a limitation to successful performance of the test, because a single needle biopsy cannot obtain enough tissue to test many kinds of anticancer agents and fibrosis secondary to the pancreatic cancer may make it difficult to collect any tissue. Thus, a better technique of collecting cancer tissue needs to be devised. In conclusion, the usefulness of the test should be confirmed in a large series of a lot of patients with advanced pancreatic cancer.

\section{References}

1) Warshaw AL, Swanson RS. Pancreatic cancer in 1988. Possibilities and probabilities. Ann Surg, 208 : 541-553, 1988.

2) Yamaguchi $T$, Saisho $H$, Ohto M, Fukuo K. Diagnostic capability and clinical usefulness of percutaneous histological biopsy of the pancreas under control on ultrasound image using a 21 gauge needle. Jpn J Gastroenterol, 87(11) : 2517$2525,1990$.

3) Sekiya S, Iijima N, Oosaki T, Takamizawa H, Tokita H. A newly developed in vitro chemosensitivity test (nuclear damage assay) : application to ovarian cancer. Gynecol Oncol, $40: 138-143,1991$.

4) Tokita $\mathrm{H}$, Tanaka $\mathrm{N}$. The in vitro cytotoxic for predicting cancer chemotherapy. Med Biol, 108:341-344, 1984.

5) General rules for chemotherapy of solid tumors. J Jpn Soc Cancer Ther, $21: 943-953,1986$. 
6) The Gastrointestinal Tumor Group. Phase 2 studies of drug combinations in advanced pancreatic carcinoma : Fluorouracil plus doxorubicin plus mitomycin $\mathrm{C}$ and two regimens of streptozocin plus mitomycin plus fluorouracil. J Clin Oncol, 4: 1794-1798, 1986.

7) Arbuck SG. Chemotherapy for pancreatic cancer. Baill Clin Gastroenterol, 4(4): 953-968, 1990.

8) Kondo $\mathrm{T}$, Imamura $\mathrm{T}$, Ichihashi $\mathrm{H}$. In virro test for sensitivity of tumor to carcinostatic agents. Gann, $57: 113-121,1966$.

9) Hamburger AW, Salmon SE. Primary bioassay of human tumor stem cells. Science, 197: 461-463, 1977.

10) Mosmann T. Rapid colorimetric assay for cellular growth and survival: application to proliferation and cytotoxicity assay. Immunol Methods, 65 : 55-63, 1983.
11) Griffin TW, Bogden AE, Reich SD, et al. Initial clinical trials of the subrenal capsule assay as apredictor of tumor response to chemotherapy. Cancer, $52: 2185-2192,1983$.

12) Yamada $Y$, Kubota T, Kawamura E, et al. Human tumor cell clonogenic assay with reference to the clinical effect of chemotherapy. Surg Res Comm, $4: 41-51,1988$.

13) Iijima N, Sekiya S, Tokita H, Takamizawa H. Basic study on in vitro chemosensitivity tests. Acta Obst Gynaec Jpn, 43( 2 ) : 191-196, 1991

14) Sternberg CN, Magill GB, Cheng EW, Applewhite A, Sordillo pp. Etoposide (VP-16) in the treatment of advanced adenocarcinoma of the pancreas. Am J Clin Oncol, 11(2) : 172173, 1988. 
Chemosensitivity testing by nuclear damage assay of needle biopsy tissue in 19 patients with advanced pancreatic cancer $P 103 \sim 108$

Hiromitsu Saisho et al.

進行萃癌の治療において抗癌剤を用いた化学療法は重 要な位置を占めるが，現在のところその治療成績はあま り期待できない，筆者らは進行膵癌治療において抗癌剤 感受性試験を応用し，化学療法の成績向上を試みた。

[対象と方法] 切除不能な進行膵癌19例（男11例，女 8 例，平均年齢64歳）に対し，経皮的針生検によって得 られた組織を用いて抗癌剤感受性試験を行った。感受性 試験は時田等によって開発された，核の形態変化を応用 したnuclear damage assay (NDA)によって行った。組織 採取は $21 \mathrm{G}$ 組織生検針を用いて超音波映像下に経皮的に 行い，得られた癌組織を細切遠心分離し，一定濃度の抗 癌剂を溶解した培盖液中で $4 \sim 8$ 時間 incubationした。 核の変化は断裂，破砕あるいは濃縮を陽性所見とし，そ の出現数を対照との間で統計的に $5 \%$ 以下の危険率で判 定した，感受性試験の成績により陽性薬剤のある場合は もっとも核変化の大きい薬郕を 1 郕，また陽性薬戍のな い場合は $5 \mathrm{FU}$ をそれぞれ単独で投与し，その効果を比較 検討した。

[成 績］19例中16例において感受性試験の判定が可

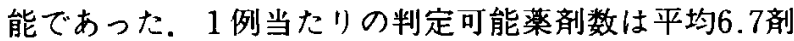
で，16例中13例に陽性薬郕が得られ，その平均は1.2剂で あった，CDDP、JM8が比較的陽性率の高い薬郕であっ た。固形癌化学療法効果判定基淮による評価では，陽性 薬剂治療群13例で Complete Response (CR) 1 例, No Cange (NC) 5 例, Progressive Desease (PD) 7 例であっ たのに対し， $5 \mathrm{FU}$ 治療群 3 例全例がPDであった。 Generalized Wilcoxon 検定では陽性薬剂治療群のほうが 5 FU治療群にくらべ，有意に生存期間の延長が認めら れ，また，それぞれの平均生存期間は 23.4 週間と11.1週 間であった. CRの得られた症例は75歳の男性で，診断時 すでに肝転移がみられた。感受性試験によりVP16が陽性 と判定され，経静脈的に $80 \mathrm{mg} / \mathrm{m} 2$ を 2 クール行った結 果, 画像上原発巣および転移巣とも消失し，1 年10力月 長期生存した。

[考察] 癌は同一組織に発生したものであっても， 抗癌凨に対する感受性は各々の症例で異なることが知ら れている。症例ことに適切な蔡剂を選択し，化学療法の 成績を向上させようとする目的で，様々な感受性試験が 考案されているが，必ずしも臨床的に応用されていると は言いがたい。今回，切除不能進行勎癌に対し，経皮的 針生検により開腹することなく組織採取し，感受性試駼 が施行可能なことを明らかにしたままた，陽性薬剤治㙩 群の成績が良好なことを示した。さらに，従来膡癌に対 しほとんど無効と報告されているVP16によりCRが得ら れたことは，感受性試験により適切な薬剤選択が行いう れば，治療成績の向上に結びつくことを示唆するものと 考えられた。
Evalution of argyrophilic nucleolar organizer regions (AgNOR) in breast cancer

P109 112

Yoshinari Ogawa et al.

[目的］AgNORは腫瘍増殖活性を反映するとされ ているが, 癌腫における予後因子としての有用性は報告 により異なる。今回，乳癌における AgNOR染色像と臨 床病理学的因子との関連および予後因子としての有用性 を検討した。

[対象と方法］ 乳癌157例（平均観察期間82力月). 对 照として乳腺線維腫瘍 9 例, 硬化性腺症 9 例, 正常乳腺 15例を用い比較検討した.AgNOR染色はCrocker法に準 してて行い， 1 症例100核の核内dot数の平均值を算出し， AgNOR score とした。

[結 果] AgNOR scoreは, 正常乳腺 $(1.97 \pm 0.22)$, 硬化性腺症 (2.19 \pm 0.26$)$, 線維腺腫 $(2.49 \pm 0.51)$ に比 し，癌腫（3.95 1.17）にて有意に高值であった（ $\mathrm{p}<$ 0.001)。乳癌においてAgNOR score は腫瘍径，リンハ節 転移との関連がみられたが，閉経の有無，組織型，エス トロゲンレセプターとの関連はみられなかった，乳癌症 例を平均 AgNOR score3.95を境として AgNOR高值群 と低值群の 2 群に分け比較すると, 高值群の健存率は低 值群に比し有意に不良であったが $(\mathbf{p}<0.05)$, 生存率に 有意差は認められなかった。多変量解析では，AgNOR scoreの独立した予後因子としての有用性は認められな かった。

[考察] AgNOR scoreは，乳癌においても腫䀛增殖 活性を反映すると考えられた。AgNOR scoreは独立した 予後因子としての有用性を認めないものの, 高値群と低 值群間の健存率に有意差が認められることより、・リンパ 節転移など他の予後因子が不明な症例においては，再発 予測因子として活用できると考えられた。 